\title{
Analisis Buku Ajar Bahasa Arab Karya Dr. D. Hidayat
}

Mabrurrosi

Sekolah Tinggi Ilmu Bahasa Arab (STIBA) Darul Ulum Banyuanyar Pamekasan mabrurrosi@gmail.com

\begin{abstract}
Books are an integral part of teaching and learning activities. So far, textbooks have become the most widely used media in transferring knowledge and knowledge to students. However, the ability to compile books properly and according to the mandate of the curriculum cannot be done by everyone. Therefore, it requires exposure and content analysis in textbooks. In this research, the learning content contained in the Arabic language book by Dr. D. Hidayat for grade $6 \mathrm{MI}$.

This study aims to describe the content of teaching materials and identify them according to the principles of teaching material analysis so that teachers can see the strengths and weaknesses of the book.

Keywords: Book Analysis, Arabic, Knowledge

Abstrak

Buku adalah bagian yang tak terpisahkan dalam kegiatan belajar mengajar. Selama ini buku ajar menjadi media yang paling banyak digunakan dalam mentranfer ilmu dan pengetahuan kepada peserta didik. Namun, kemampuan menyusun buku dengan baik dan sesuai amanah kurikulum tidak bisa dilakukan oleh semua orang. Oleh sebab itu, diperlukan paparan dan analisis konten dalam buku ajar. Dalam penelitian ini akan dipaparkan konten pelajaran yang terdapat dalam Buku Bahasa Arab karya Dr. D. Hidayat untuk kelas 6 MI.

Penelitian ini bertujuan untuk mendeskripsikan konten bahan ajar dan mengidentifikasinya sesuai dengan kaidah analisis bahan ajar sehingga para guru dapat melihat kelebihan dan kekurangan yang dimiliki buku tersebut.

Kata Kunci: Analisis, Buku Ajar, Bahasa Arab
\end{abstract}




\section{Pendahuluan}

Dalam pelaksanaan proses pembelajaran pemanfaatan sumber belajar sangat penting. Menurut Munir (2008) mendefinisikan, bahwa yang dimaksud dengan sumber belajar adalah bahan-bahan yang dapat dimanfaatkan dan diperlukan untuk membantu guru maupun siswa dalam proses pembelajaran.

Dalam definisi lain sumber belajar (learning resources) adalah semua sumber baik berupa data, orang maupun wujud tertentu yang dapat digunakan oleh peserta didik dalam belajar, baik secara terpisah maupun secara terkombinasi sehingga mempermudah peserta didik dalam mencapai tujuan belajar atau kompetensi tertentu.

Sumber belajar dapat berupa buku teks, media cetak, media elektronik, narasumber, lingkungan alam sekitar dan lain sebagainya yang dapat meningkatkan keefektifan proses pembelajaran. Diantara sekian banyak jenis sumber belajar tersebut, buku teks pelajaran merupakan salah satu sumber belajar yang paling sering digunakan dalam proses pembelajaran. Namun ditinjau dari aspek penyajiannya, buku teks pelajaran sering kali disajikan dalam bentuk yang masih sederhana, berupa gambar-gambar yang terkadang membuat siswa belum mampu memahami secara penuh isi dari materi yang disajikan.

Bahan ajar atau materi pembelajaran (instructional materials) secara garis besar terdiri dari pengetahuan, keterampilan, dan sikap yang harus dipelajari siswa dalam rangka mencapai standar kompetensi yang telah ditentukan (Depdiknas, 2006: 4). Dalam Peraturan Menteri Pendidikan Nasional No.11 tahun 2005 Pasal 1 menyatakan bahwa buku teks pelajaran adalah buku acuan wajib untuk digunakan di sekolah-sekolah yang memuat materi-materi pembelajaran dalam rangka peningkatan keimanan dan ketaqwaan, budi pekerti dan kepribadian, kemampuan penguasaan ilmu pengetahuan dan teknologi, kepekaan dan kemampuan estetis, potensi fisik dan kesehatan yang disusun berdasarkan standar nasional pendidikan. 
Menurut Lange (Tarigan, 2009) buku teks adalah buku standar/ baku setiap cabang khusus studi dan dapat terdiri dari dua tipe yaitu buku pokok/utama dan suplemen/tambahan. Lebih terperinci lagi, menurut Bacon (Tarigan, 2009) buku teks adalah buku yang dirancang untuk penggunaan di kelas, dengan cermat disusun dan disiapkan oleh para pakar atau para ahli dalam bidang itu dan dilengkapi dengan sarana-sarana pengajaran yang sesuai dan serasi. Sedangkan menurut Buckingham (Tarigan, 2009) buku teks adalah sarana belajar yang biasa digunakan di sekolah-sekolah dan di perguruan tinggi untuk menunjang suatu program pengajaran dalam pengertian modern dan yang umum dipahami.

Berdasarkan beberapa pendapat mengenai buku teks di atas, maka dapat disimpulkan bahwa buku teks adalah buku pelajaran dalam bidang studi tertentu yang merupakan buku standar, yang disusun oleh para pakar dalam bidang tertentu untuk maksud maksud dan tujuan instruksional, yang dilengkapi dengan sarana-sarana pengajaran yang serasi dan mudah dipahami oleh para pemakainya.

Bahan ajar disusun dengan tujuan sebagai berikut: (a) Membantu siswa dalam mempelajari sesuatu. (b) Menyediakan berbagai jenis pilihan bahan ajar yang dimaksud adalah agar siswa tidak terpaku oleh satu sumber saja (c) Memudahkan guru dalam pelaksanaan pembelajaran karena bahan ajar disusun sendiri dan disampaikan dengan cara yang bervariatif. (d) Agar kegiatan pembelajaran menjadi lebih menarik erbagai jenis bahan ajar yang bervariatif diharapkan kegiatan pembelajaran tidak monoton.

Bahan ajar mempunyai beberapa fungsi sebagai berikut: (a). Pedoman bagi guru yang akan mengarahkan semua aktivitasnya dalam proses pembelajaran, sekaligus merupakan substansi yang seharusnya diajarkan kepada siswa (b) Pedoman bagi siswa yang akan mengarahkan semua aktivitasnya dalam proses pembelajaran sekaligus substansi kompetensi yang seharusnya dikuasainya. (c)Alat evaluasi pencapaian dan penguasaaan hasil pembelajaran yang telah dilakukan. 
Berdasarkan teknologi yang digunakan, bahan ajar dapat dikelompokkan menjadi empat kategori, yaitu bahan cetak (printed), seperti lembar kerja siswa. Bahan ajar dengar (audio) seperti kaset,radio, dan lain-lain, Bahan ajar pandang dengar (audio visual)seperti video compact disk, film. Bahan ajar multimedia interaktif (interactive teaching material) seperti CAI (Computer AssistedInstruction), compact disk (CD) multimedia pembelajaran interaktif,dan bahan ajar berbasis web (web based learning materials). Bahan ajar atau buku pelajaran termasuk dalam kategori bahan cetak (printed) yaitu buku teks.

Buku teks merupakan salah satu jenis buku pendidikan.Menurut Loveridge buku teks adalah buku sekolah yang memuat bahan yang telah diseleksi mengenai bidang studi tertentu, dalam bentuk tertulis yang memenuhi syarat tertentu dalam kegiatan belajar mengajar, disusun secara sistematis untuk diasimilasikan.

Dalam pandangan Chambliss dan Calfee (1998) menjelaskan bahwa buku teks adalah alat bantu siswa untuk memahami dan belajar dari hal-hal yang dibaca dan untuk memahami dunia (di luar dirinya). Buku teks memiliki kekuatan yang luar biasa besar terhadap perubahan otak siswa.Buku teks dapat mempengaruhi pengetahuan anak dan nilai-nilai tertentu.Buku teks atau buku pelajaran adalah sekumpulan tulisan yang dibuat secara sistematis berisi tentang suatu materi pelajaran tertentu, yang disiapkan oleh pengarangnya dengan menggunakan acuan kurikulum yang berlaku.Substansi yang ada dalam buku diturunkan dari kompetensi yang harus dikuasai oleh siswa (Direktorat Pendidikan Menengah Umum (2004: 3).

Buku teks adalah buku pelajaran yang disusun oleh para ahli atau pakar dalam bidangnya untuk menunjang program pembelajaran yang telah digariskan oleh pemerintah. Beberapa hal mengenai buku pelajaran adalah sebagai berikut: a) Buku teks itu selalu buku pelajaran yang ditujukan bagi siswa pada jenjang pendidikan tertentu, b) Buku teks itu selalu berkaitan dengan bidang studi tertentu, c) Buku teks itu selalu buku yang standar, d) 
Buku itu biasanya disusun dan ditulis oleh para pakar (ahli, ekspert) di bidangnya masingmasing, e) Buku teks itu ditulis untuk tujuan instruksional tertentu, f) Buku teks juga biasanya dilengkapi dengan sarana pengajaran, g) Buku teks itu biasanya ditulis untuk jenjang pendidikan tertentu, h) Buku teks itu selalu ditulis untuk menunjang sesuatu progaram pengajaran. (H.R.Tarigan, 1986)

Jenis pengembangan bahan ajar meliputi penyusunan, pengadaptasian, pengadopsian, perevisian, dan penerjemahan. Uraian lebih lengkapnya adalah sebagai berikut: 1) Penyusunan, 2) Pengadaptasian, 3) Pengadopsian, 4) Perevisian, 5) Penerjemahan.

Setiap buku teks pelajaran diharapkan memenuhi standar-standar tertentu. Standar yang dimaksud meliputi persyaratan, karakteristik, dan kompetensi minimum yang harus terkandung di dalam suatu buku pelajaran. Standar penilaian dirumuskan dengan melihat tiga aspek utama, yaitu materi, penyajian, dan bahasa/keterbacaan.

Dalam setiap penyampaian makna dan pesan dari satu bahasake bahasa yang lain atau yang biasa kita kenal penerjemahan, adabeberapa proses yang dilalui untuk menghasilkan terjemahan tersebut.Proses penerjemahan adalah rangkaian kegiatan yang dilakukanpenerjemah dalam mentransfer pesan dari bahasa sumber ke bahasasasaran.

Adapun proses yang dilakukan dalam penerjemahan: Pertama, Perencanaan, yaitu proses yang erdiri dari identifikasi dan pengenalan terhadap cakupan kebutuhan dari bahan yang akan diterjemahkan (termasuk di dalamnyapenggunaan istilah). Kedua Analisis informasi terdiri dari menganalisa teks sumber dan merencanakan kegitan menerjemahkan dengan memilih strategi tepat untuk menghasilkan terjemahan yang baik. Ketiga menerjemahkan, yaitu penerjemah menerapkan strategi yang telah dipilih untuk kemudian menerapkannya untuk mentransfer pesan dari bahasa sumber ke bahasa sasaran dengan baik. 
Keempat, merevisi yaitu proses membaca meninjau kembali hasil terjemahannya dan merevisi apabila ada kesalahan atau terjemahan yang kurang baik. Kelima, sditing / koreksi, biasanya dilakukan oleh pihak lain, biasa disebut editor. Keenam mereview, dilakukan oleh pihak lain sebagai upaya untuk menjaga kualitas hasil terjemahan dengan memperhatikan integritas kesatuan antar kalimat maupun paragraf agar menjadi terjemahan yang baik. Ketujuh, penyelesaian akhir, yaitu dengan tuntas dan memastikan seluruh pekerjaan menerjemahkan telah diselesaikan.

Selanjutnya Guru harus mampu memilih buku teks yang baik dan sesuai dengan tuntutan kurikulum. Menurut Geene dan Pety, buku teks yang baik adalah buku teks yang berkualitas atau bermutu.Menyodorkan sepuluh kategori yang harus dipenuhi buku teks yang berkualitas.Sepuluh kategori buku teks yang baik adalah sebagai berikut: ( Tarigan, 1986: 21), (1) Buku teks haruslah menarik minat siswa, (2) Buku teks haruslah mampu memberikan motivasi kepada para siswa.(3) Buku teks haruslah memuat ilustrasi yang menarik siswa. (4) Buku teks harus mempertimbangkan aspek-aspek linguistik ssesuai dengan kemampuan para siswa. (5) Isi buku teks haruslah berhubungan erat dengan pelajaran-pelajaran lainnya. (6) Buku teks haruslah dapat menstimuli, merangsang aktivitas-aktivitas pribadi para siswa (7) Buku teks haruslah dengan sadar dan tegas menghindar dari konsepkonsep yang samar-samar sehingga tidak membingungkan siswa. (8) Buku teks haruslah mempunyai "point of view". (8) Buku teks haruslah mamu memberi pemantapan, penekanan pada nilai-nilai anak dan orang dewasa. (9) Buku teks haruslah dapat menghargai perbedaan perbedaan pribadi para pemakainya.

Lebih lanjut Tarigan (1986:22) menyebutkan ada sebelas aspek untuk menentukan kualitas buku teks, yaitu (1) memiliki landasan prinsip dan sudut pandang yang berdasarkan teori linguistik, ilmu jiwa perkembangan, dan teori bahan pembelajaran, (2) kejelasan konsep, (3) relevan dengan kurikulum yang berlaku, (4) sesuai dengan minat siswa, (5) menumbuhkan motivasi belajar, (6) merangsang, menantang, dan menggairahkan aktivitas siswa, (7) ilustrasi tepat 
danmenarik, (8) mudah dipahami siswa, yaitu bahasa yang digunakan memiliki karakter yang sesuai enan tingkat perkembangan bahasa siswa, kalimat-kalimatnya efektif, terhindar dari makna ganda, sederhana, sopan dan menarik, (9) dapat menunjang mata pelajaran lain, (10) menghargai perbedaan individu, kemampuan, bakat, minat, ekonomi, sosial dan budaya, (11) memantapkan nilai-nilai budi pekerti yang berlaku di masyarakat.

Menurut PP No.19/2005, buku teks yang baik memiliki empat komponen yaitu komponen kelayakan isi, kebahasaan, penyajian, dan kegrafikaan, beserta penjelasannya,Sebuah buku teks pelajaran yang baik adalah buku yang; (a) Memperhatikan komponen kelayakan isi, minimal mengacu pada sasaran yang akan dicapai peserta didik, dalam hal ini adalah standar kompetensi (SK dan KD). (b) Memperhatikan komponen kebahasaannya. Untuk itu, bahasa yang digunakan harus mengacu pada kaidah-kaidah kebahasaan yang baik dan benar, yang dapat dikomunikasikan kepada pembaca (khususnya guru dan peserta didik) secara logis, mudah diterima sesuai dengan tahapan perkembangan kognitif pembaca. (c) Berisi konsep-konsep disajikan secara menarik, interaktif dan mampu mendorong terjadinya proses berpikir kritis, kreatif, inovatif dan kedalaman berpikir, serta metakognisi dan evaluasi diri. (d) disajikandalam wujud tampilan yang menarik dan menggambarkan ciri khas buku pelajaran, kemudahan untuk dibaca dan digunakan, serta kualitas fisik buku.

Bahasa Arab termasuk mata pelajaran yang banyak diajarkan di sekolah. Di lingkungan Departemen Agama, bahasa Arab wajib diajarkan mulai dari tingkat Madrasah Ibtidaiyah (MI), Madrasah Tsanawiyah (MTs), dan Madrasah Aliyah (MA). Di lingkungan Departemen Pendidikan Nasional, bahasa Arab disajikan sebagai bahasa asing pilihan untuk mata pelajaran pilihan di SLTA.Bahkan, di sekolah-sekolahyang berada di bawah naungan organisasi keagamaan tertentu, bahasa Arab wajib diajarkan di tingkat SD, SLTP, dan SLTA.Melihat betapa pentingnya bahasa Arab dalam dunia 
pendidikan di Indonesia, bahasa tersebut perlu mendapat perhatian untuk dikaji dan dikembangkan pengajarannya.

Kedudukan mata pelajaran Bahasa Arab di Sekolah Dasar samadengan kedudukan bahasa-bahasa lain dalam kurikulum di Sekolah. Tidak semua di pendidikan dasar memberlakukan mata pelajaran bahasa Arab sama dengan mata pelajaran lainnya. Dalam struktur kurikulum di Madrasah Ibtidaiyah mata pelajaran bahasa Arab adalah mata pelajaran yang wajib diajarkan mulai dari kelas bawah; yaitu kelas I sampai kelas III juga diajarkan di kelas atas, yaitu kelas IV sampai kelas VI.

Di Madrasah Ibtidaiyah Bahasa Arab berfungsi sebagai bahasa agama, ilmu pengetahuan, dan komunikasi.Oleh karena itu pembelajaran bahasa Arab selalu terkait dan saling menunjangdengan mata pelajaran Agama Islam lainnya.Melalui pembelajaran bahasa Arab di tingkat pendidikan dasar, diharpkan peserta didik dapat berkomunikasi dan memahami bacaan-bacaan dalam bahasa Arab secara sederhana.

Hasil-hasil penelitian menunjukkan bahwa secara umum, pengajaran bahasa Arab di Indonesia menghadapi banyak kendala yang perlu dicarikan jalan keluarnya baik di MI (Khasairi dkk. 2002), Sebagai penyempurnaan kurikulum 2004 (KBK), KTSP merupakan kurikulum operasional yang disusun dan dilaksanakan oleh masing-masing satuan pendidikan/sekolah. Departemen Pendidikan Nasional mengharapkan paling lambat tahun 2009/2010 semua sekolah telah melaksanakanKTSP. Dalam kaitan itu, Badan Standar Nasional Pendidikan (BSNP) telah membuat panduan penyusunan KTSP sebagai acuan bagi satuan pendidikan SD/MI/SDLB, SMP/MTs/ SMPLB, MA/MA/- SMALB, dan SMK/MAK (Muslich 2007a:10). KTSP dikembangkan berdasarkan prinsip-prinsip (1) berpusat pada potensi, perkembangan, kebutuhan, dan kepentingan peserta didik dan lingkungannya; (2) beragam dan terpadu; (3) tanggap terhadap perkembangan ilmu pengetahuan, teknologi dan seni; (4) relevan dengan kebutuhan kehidupan, menyeluruh dan berkesinambungan; (5) belajar sepanjang hayat; dan (6) 
seimbang antara kepentingan nasional dan kepentingan daerah. Komponen KTSP ada empat, yaitu (1) tujuan pendidikan tingkat satuan pendidikan, (2) struktur dan muatan KTSP; (3) kalender pendidikan; dan (4) silabus dan Rencana Pelaksanaan Pembelajaran (RPP) (Muslich 2007a: 11-12).

Bidang Studi Bahasa Arab dari segi keselarasan materi pada setiap tingkat satuan pendidikan apabila dikaji, Kurikulum 2004 berisi Standar Kompetensi MI untuk pelajaran bahasa Arab.Standar Kompetensi Bahan Kajian terdiri atas empat keterampilan, yakni menyimak, berbicara, membaca, dan menulis. Dalam ruang lingkup, disebutkan bahwa untuk MI kosakata yang perlu dikuasai secara kumulatif berjumlah 300 kosakata dan ungkapan/idiom yang komunikatif dan tinggi frekuensi pemakaiannya dalam kehidupan seharihari peserta didik, baik di lingkungan madrasah maupun di rumah (Depag 2004a: 142-143).

Mata pelajaran bahasa Arab bertujuan untuk mengembangkan kemampuan siswa berkomunikasi dalam bahasa tersebut, baik dalam bentuk lisan dan tulis.Memanfaatkan bahasa Arab untuk menjadi alat utama belajar, khususnya dalam mengkaji sumber-sumber ajaran Islam dan mengembangkan pemahaman tentang saling keterkaitan antara bahasa dan budaya.

Setiap mata pelajaran yang disampaikan di kelas selalu menggunakan buku teks pelajaran, tidak terkecuali mata pelajaran bahasa Arab di Madrasah Ibtidaiyah.Yang menjadi kajian dalam penelitian ini adalah buku yang berjudul “Pelajaran Bahasa Arab/ تعليم اللغة العربية karya Dr. D. Hidayat yang diterbitkan oleh Karya Toha Putra. Buku teks pelajaran ini dibuat berdasarkan Kurikulum Tingkat Satuan Pendidikan (KTSP) dan berstandar Isi Madrasah Ibtidaiyah tahun 2008.

\section{Identitas Buku Pelajaran}

Nama Buku yang menjadi objek penelitian ini adalah Pelajaran Bahasa Arab "تعليم اللغة العربية" Madrasah Ibtidaiyah Kelas 6 ditulis oleh Dr. D. Hidayat. 
Cetakan 1 (pertama), Pebruari, diterbitkan oleh PT. Karya Toha Putra, Semarang Tahun 2009 dengan Kapasitas viii+96 halaman; 26 cm.

Paparan konten buku sebagaimana dalam tabel berikut:

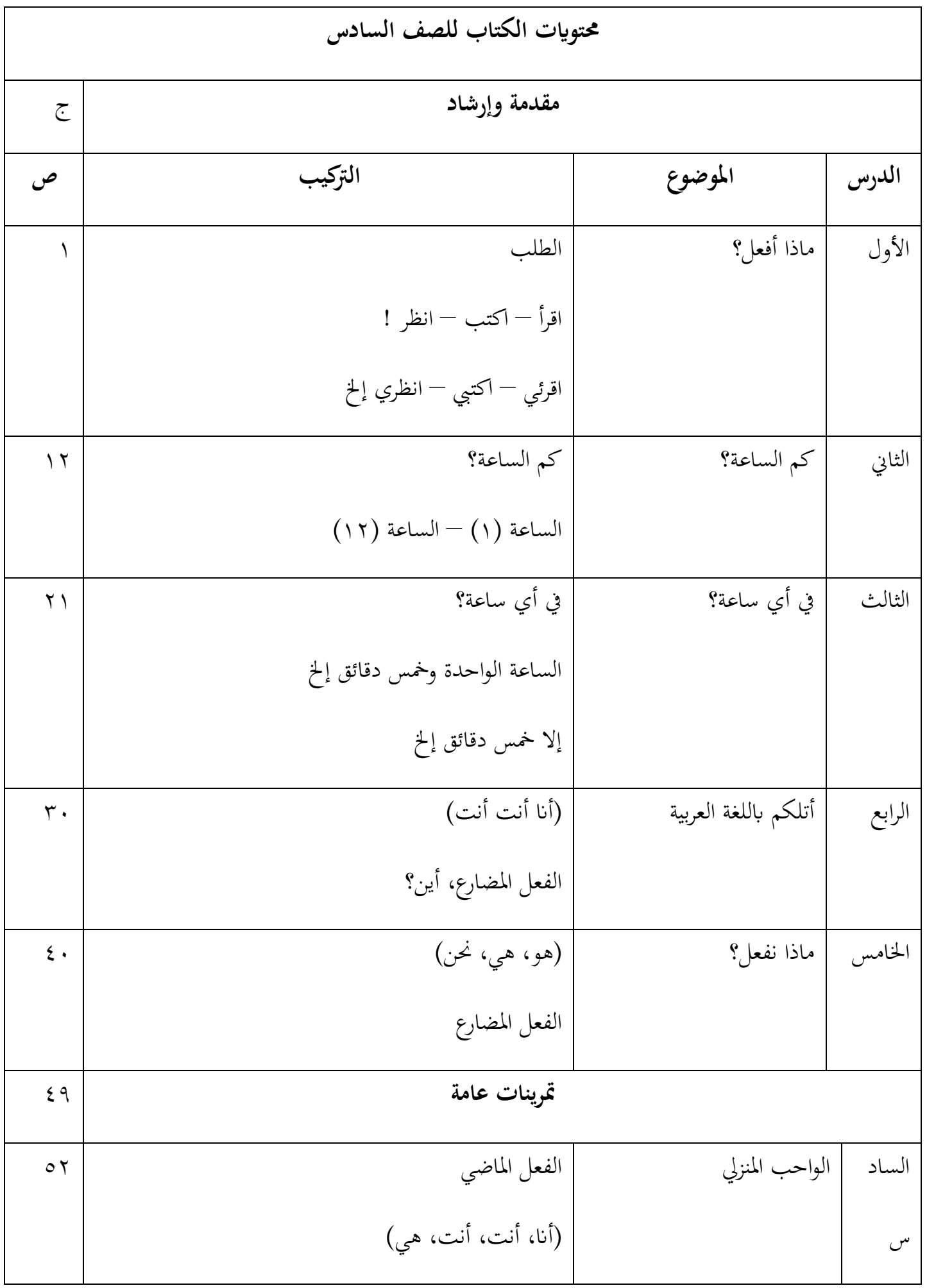




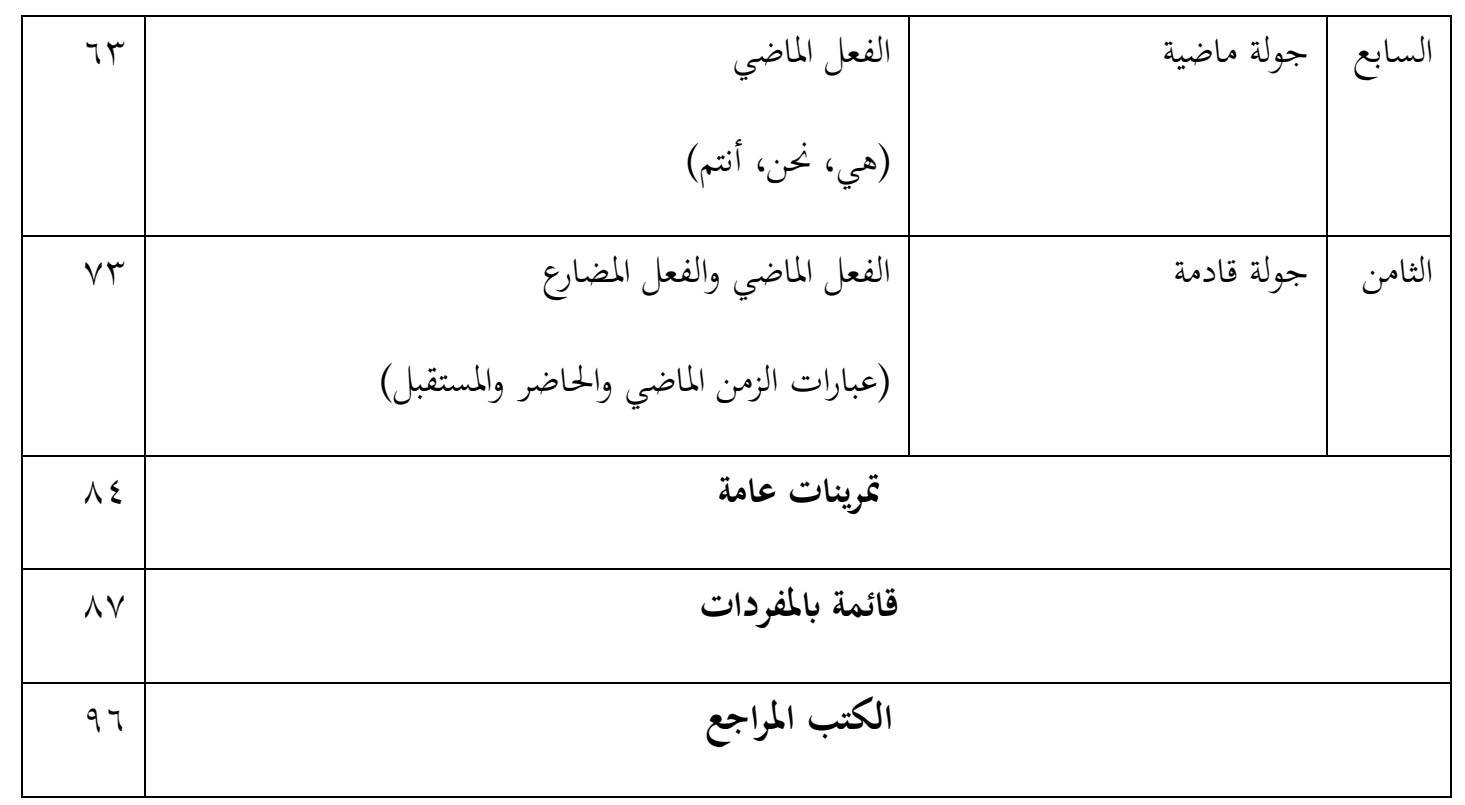

\begin{tabular}{|c|c|}
\hline جملة المفردات & الدرس \\
\hline 17 & الأول \\
\hline 19 & الثاني \\
\hline ir & الثالث \\
\hline 11 & الرابع \\
\hline 11 & الخنامس \\
\hline ir & السادس \\
\hline 19 & السابع \\
\hline ^ عبارات & الثامن \\
\hline$r \cdot q$ & مجموع كلي \\
\hline
\end{tabular}

*) Jumlah keseluruhan mufradat yang terdapat dalam قائمة بالمفردات adalah 242 kosa kata. 


\section{Teknik Pembelajaran}

Dalam buku ajar ini diawali dengan teknik pembelajaran (إرشاد عام) yang isinya sebagai berikut: Dalam membuat persiapan pembelajaran suatu dars, yang pertama kali dilakukan adalah pengembangan topik-topik dalam silabus kurikulum kelasVI menjadi dars-dars, lalu penentuan struktur atau pola kalimat apa yang cook untuk setiap dars, seperti yang tampak hasilnya dalam 'daftar isi' (muhtawayat) buku. Kemudian penentuan standar kompetensi dan kompetensi dasar dengan merujuk pada rumusan yang tercantum pada silabus kurikulum.

Demikian selanjutnya KD untuk 'membaca' dan'menulis' dengan merujuk pada rumusa silabus kurikulum. Kemudian atas dasa kompetensi dasar tersebut dapta dirumuskan 'indikator pencapaian' dars tersebut, seperti diberikan contohnya pada setiap dars dalam buku ini.

Sesuai dengan SK dan KD dalam kurikulum, materi pelajaran dalam buku ini untuk setiap dars ditampilkan dalam empat komponens, satu dengan yang lain saling berkaitan (Nazriyyat Al-Wahdah), yaitu: 1) Al-Hiwar, mengembangkan keterampilan berbicara; 2) Al-Tarkib, mengembangkan keterampilan menerapkan qawaid bahasa arab agar ketrmpilan berbicara, mebaca dan menulis dapat berfungsi sebagai alat komunikasi yang baik dan benar; 3) Al-Qiraah, mengembangkan keterampilan membaca; dan 4) Al-Kitabah, mengembangkan keterampilan menulis.

Sedangkan komponen menyimak tidak diajarkan tersendiri, melainkan diintegrasikan dalam kegiatan menirukan, mengulangi ucapan guru, mendengarkan dan memperagakan, pada saat pembelajaran hiwar, juga melalui kegiatan mendengarkan bacaan guru dan bacaan sesama siswa pada saat pembelajaran qiraah. Kegiatan semisal ini besar manfaatnya untuk pengembangan keterampilan 'menyimak', jika dialakukan dengan penuh keungguhan.

Agar pembelajaran berjalan secara efektif dan efisien, dibawah ini dikemukakan langkah-langkah kegiatan yang perlu diperhatikan dalam 
mengejarkan materi hiwar, tarkib, qiraah dan kitabah yang terdapat dalam buku Pelajaran Bahasa Arab MI Kelas VI ini.

Pembelajaran Al-Hiwar (dialog): 1) Guru membaca mufradat baru (yang tertera di papan tulis atau dalam buku pelajara), satu persatu, lalu ditirukan oleh semua siswa. 2) Guru menjelaskan makna tiap mufradat dan ungkapan baru, sedapat mungkin tanpa menggunakan terjemah. 3) Pelajaran hiwar dimulai dengan menjelaskan secara singkat tema dan isi atau jalan cerita hiwar yang akan dipelajari, bila perlau dalam bahasa Indonesia. Umpamanya pada hiwar dars (4): “ilyas dan adiknya Fatimah berada di perpustakaan madrasah. Ketika siap-siap akan pulang mereka dihampiri oleh seorang petugas perpustakaan. Petugas itu tertarik dengan Ilyas dan Fatimah, karena mereka berdua tampak dapat berkap dalam bahasa Arab. 4) Guru (atau rekaman suara) mengucapkan materi suatu hiwar kalimat per kalimat, sementara siswa menyimak ucapan guru dengan penuh perhatian. 5) Guru mengucapkan materi hiwar kalimat per kalimat dan segera ditirukan oleh seluruh siswa. 6) Guru menjelaskan makna materi hiwar, dengan cara tanya jawab, isyarat, peragaan atau dramatisasi dengan menggunakan media yang digunakan ketika menjelaskan makna mufradat baru, serapat mungkin tanpa menggunakan terjemah dan kata pengatar dalam bahasa Indoneisia. 7) Siswa secara berpasangan melakukan latihan (tadribat) hiwar, dngan bimbingan guru. 8) Setelah siswa menguasai materi hiwar dengan baik, mereka diminta untuk membaca materi hiwar denan baik dan benar, dalam buku pelajaran atau pada papan tulis yang terlah disiapkan sebelumnya.

Dalam pembelajaran Al-Tarkib (struktur kalimat), dalam kegiatan tarkib siswa sedapat mungkin tidak melihat materi pelajaran dalam buku pelajaran, melainkan pada papan tulis yan dipersiapka sebelumnya di samping membaca materi pelajaran dan tanyat jawab, maka terjemah seringkali dirasakan sebagai suatu cara yang efektif, agar siswa memahami makna struktur kalimat yang dipelajari dengan benar dan tepat. Kegiatan 'latihan' (tadribat) bertujuan untuk memantapkan penguasaan materi tarkib, dan dilakukan oleh siswa secara 
perorangan atau berpasangan, setelah guru menjelaskan contoh baaimana cara melakukannya.

Langkah-langkah Pembelajaran Al-Qiraah (membaca) meliputi: 1) Diawali denga pendahuluan, berupa tanya jawab antara guru dan siswa sehingga diketahui gambaran umum kandugnan bahan qiraah. 2) Guru membaca materi qiraah, semenatra itu siswa mendengarkannya dengan penuh perhatian. Pada saat-saat tertentu dapat juga salah seorang siswa yang baik bacaannya melakukan peranan ini. 3) Siswa seluruhnya menirukan bacaan guru kalimat per kalimat. 4) Guru meminta siswa secara bergiliran untuk membaca beberapa bagian atau seluruh materi qiraah sesuai waktu yang tersedia. Di sini kesalahan bacaan seorang siswa dibertulkan oleh temannya atau oleh guru sendiri, dengan tidak memotong bacaan siswa di tegnah bacaan suatu kalimat (jumlah). 5) Siswa diminta menjawab beberapa pertanyaan tentan kandunga bahan qiraah. Sebaiknya dalam qiraah digunakan papan tulis dengan tangkai penunjuknya, agar jelas bagi siswa antara ucapan guru dan kata yang dibacanya/ditunjuknya, sebelum mereka membaca metri qiraah dalam buku pelajaran.

Langkah-langkah pembelajaran Al-Kitabah (menulis) meliputi: 1) Kegiatan kitabah jika masih kiperlukan, dimulai dengan latihan menulis hruuf arab dengan cara imla' (dikte) melaui imla' manqul, atau imla' manzur atau imla' ikhtibari tergantung kemampuan siswa. 2) Kegiatan insya' yang dilakukan dengan insya' muwajjah selain untuk meningkatkan keteraampilan menulis huruf arab, juga sekaligus untuk memantapkan penguasaan materi pelajaran yang telah dipelajari melalui kegiatan hiwar, tarkib dan qiraah.

Peranan guru di sini ialah: 1) Menjelaskan cara mengerjakan insya muwajjah; 2) Mengoreksi pekerjaan siswa, yang dalam waktu-waktu tertentu dapat dilakukan dengan cara tukar menukar koreksi sesama siswa; 3) Mencatat kesalahan pekerjaan siswa, baik kesalahan perorangan maupun kesalahan umum yang dilakukan oleh semua atau sebagian besar siswa; 4) Menjelaskan kesalahan perorangan kepada siswa yang bersangkutan dan menjelaskan 
kesalahan umu kepada siswa seluruhnya; 5) Kegiatan insya selesai, setelah guru mencatat nilai lathan dan setelah siswa menyalin kembali materi latihan dengan memperhatikan hasil koreksian. Untuk menghemat waktu, sebagian atau seluruh kegiatan kitabh dapat dilakukan dirumah (PR), dan tidak usah menunggu selesainya qiraah, sebab tidak sedikit materi insya yang dapat dilakukan siswa langsung seelah selesai kegiatn tarkib.

\section{Pembelajaran Mufradat}

Daftar kata pada bagian akhir buku ini disusun dengan urutan huruf hijaiyyah, dan perlu dijelaskan sejark awal kepada siswa bagaimana cara memanfaatkannya. Mereka perlu dibiasakan mencari makna suatu kata, terutama ketika belajar sendiri di rumah. Jumlah kata dalam Daftar Mufradat sebanyak 240 kosa kata.

Akhirnya pelu ditegaskan, bahwa teknik pembelajaran yang disampaikan di atas hanyalah merupakan salah satu model yang perlu dikembangkan menjadi model pembelajaran yang efektif dan efisien, disertai upaya maksimal untuk menggunakan bahasa Arab dalam kegiatan sehari-hari di lingkunang madrasah, sesui dengan kemampuan siswa.

\section{Standar Kompetensi dan Indikator}

Pola Standar Kompetensi meliputi; Menyimak, berbicara, membaca dan menulis dalam bahasa arab dengan pola kalimat dasar yang munggunakan beberapa 'kata kerja perintah' yang diperlukan dalam pembelajaran sehari-hari.

Pola Indikator dalam setiap dars seperti dibawah ini;

\section{المفردات والحوار}

1) Melafalkan mufradat tentang kata kerja perintah (الطلب) yang digunakan dalam kegiatan sehari-hari dengan makhraj dan panjang pendek yang benar;

2) Menyebutkan arti mufradat tentang الطلب dengan benar;

3) Memperagakan kata-kata kerja الطلب yang diajarkan;

4) Melafalkan hiwar tentang الطلب dengan makhraj serta intonasi yang benar; 


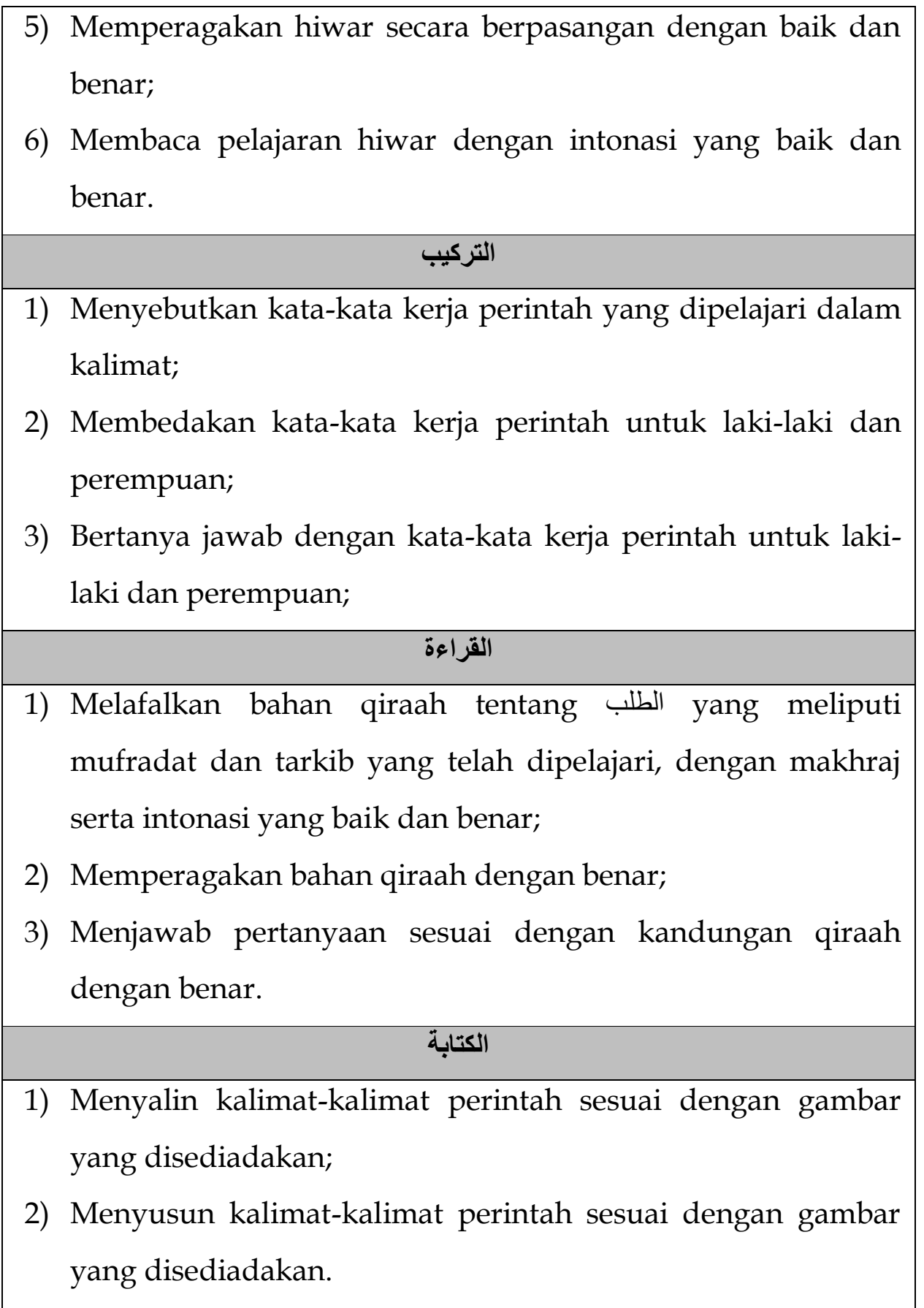

\section{Bentuk Latihan}

Bentuk latihan dalam buku pelajara bahasa Arab ini sebagai berikut; Pertama, Formatif, terdiri dari: (a) Tadribat ; latihan menyampaikan ungkapan berbahasa arab kata kerja perintah (hal. 7), (b) Praktek / peragaan ; hal. 8, 34, 57, (c) Menjawab soal / pertanyaan uraian sesuai materi; hal. 8, 20, 29, 46, 72, d) Menyalin kalimat ; hal. 9, 29, 38 , 61, 71, 82, (e) Memilih / menentukan benar 
dan salah; 19, 59, 60, 71, 79, 80, 82, (f) Menjodohkan ; hal. 27, 46, (g) Melengkapi / melengkapi ; hal. 34, 36, 44, 56, dan (h) Menyusun ; hal. 48. Kedua, Sumatif, meliputi: (1) Tamrinat 'aamah (20 soal pilihan ganda), dan (5 soal uraian); hal. 49 dan 84 .

\section{Hasil Analisis}

Dari hasil penelitan dan pembahasan yang telah disebutkan dalam babsebelumnya, maka analisis ini dapat disimpulkan sebagai berikut: Pertama, relevasi isi buku teks pelajaran bahasa Arab dengan kurikulum Buku Pelajaran Bahasa Arab "تعليم اللغة العربية"karya Dr. D. Hidayat penerbit Karya Toha Putra Semarang adalah salah satu buku yang digunakan guru dalam pembelajaran bahasa Arab. Penulisan makalah inilebih menganalisis buku pelajaran bahasa Arab kelasVI (enam).Pemaparan standar isi dalam buku tersebut dipaparkansecara lugas. Hal ini tercantum pada bagian analisis programpengajaran yang memuat standar Kompetensi (SK) Kompetensi Dasar (KD) dalam irsyad 'aam atau teknik pembelajaran, (D. Hidayat:2009, هـ هـ (.)

Standar kompetensi yang dicantumkan sudah mencakup keempat aspek keterampilan berbahasa, meliputi menyimak (الإستماع), berbicara ( المحادثة), membaca ( القراءة ), dan menulis ( الكتابة). Buku ini dibagi menjadi dua bagian, yaitu semester pertama dan semester kedua.Setiap tema yang dibahas dalam pokok bahasan didukung pola kalimat yang disesuaikan dengan kaidah qawaid (nahwu sharaf).Pada semester pertama pola kalimat yang dibahas adalah fi'il amar, isim istifham sa'ah, ism dlamirmukhathab/mukhathabah dan ghaib/ghaibah dan, fi'il mudlari'. Dan pada semester kedua berisi pola kalimat yang membahas tentang angka isim dlamir + fi'il madli, fi'il madli dan fi'il mudlari' (zaman madli, hadlir dan mustaqbal).

Kedua, Standar Penyajian Materi setiap Pokok Bahasan. Dalam hal kelayakan isi di buku teks Pelajaran Bahasa Arab “ت ditinjau dari aspek kesesuaian dengan kurikulum yang berlaku (KTSP) sudah sesuai dengan standar isi yang ditetapkan pemerintah, karena setiap standar yang ditetapkan untuk mata pelajaran bahasa (Arab) memuat komponen bahasa pada 
umumnya yaitu menyimak (mendengarkan), berbicara, membaca dan menulis. Setiap penjabaran komponen standar kompetensi maupun kompentensi dasar disesuaikan dengan keempat aspek keterampilan berbahasa.

Ditinjau dari aspek isi, buku teks pelajaran bahasa Arab ini memuat informasi, pesan, dan pengetahuan yang dituangkan dalam bentuk tertulis yang dikomunikasikan kepada pembaca (khususnya guru dan siswa) secara logis, mudah diterima sesuai dengan tahapan perkembangan kognitif pembaca. Sebelum masuk pokok bahasan, buku ini diawali dengan pengantar yang menginformasikan kepada pembaca (siswa) tentang petunjuk penggunaan buku mulai dari informasi; Pertama kosa kata (mufrodhat) berupa daftar katakata yang dipergunakan setiap pokok bahasan/materi. Kedua berisi informasi tentang attarkib yang disajikan dalam bentuk kaidah bahasa (tata bahasa) yang dipergunakan dan berkaitan dengan pokok bahasan. Ketiga, berisi informasi tentang empat aspek keterampilan bahasa disertai pemaparan standar kompentensinya dan kompetensi dasarnya yang disajikan secara runtut.Setiap keterampilan juga disesuaikan dengan pokok bahasan. Di samping itu buku ini disusun berdasarkan nazariyyat la-wihdah (satu dengan yang lain saling berkaitan).

Selain petunjuk informasi untuk siswa buku tersebut juga memuat petujuk / teknik pembelajaran untuk guru (إرشاد عام). Dalam hal ini dibahas tentang teknik-teknik yang harus disampaikan oleh guru dalam proses pembelajaran khususnya dalam hal pembelajaran empat keterampilan, membaca, menulis, berbicara dan mendengar (menyimak). Pemilihan tema pokok bahasan yang disajikan adalah tema yang berdekatan dengan lingkungan siswa, seperti tema apa yang akan aku lakukan, tanya jawab tentang jam, pekerjaan rumah, jalan-jalan yang telah dilakukan dan yang akan dilaksanakan.Ditinjau dari aspek penyajian ilustrasi baik berupa gambar maupun grafik, dalam buku teks pelajran bahasa Arab Pelajaran Bahasa Arab "تعليم اللغة العربية", bentuk ilustrasi yang dibuat adalah gambar-gambar yang berkaitan dengan tema-tema yang dimaksud dalam setiap pokok 
bahasan.Meskipun dari gambar ilustrasi yang dibuat tidak menggunakan warna-warni, sesuai dengan aslinya,hanya hitam, putih dan hijau, namun secara tematik gambar yang disajikan sudah sesuai dan cukup menarik siswa untuk memahami konteks materi.

\section{Kelebihan dan Kekurangan Buku Teks Bacaan.}

Pertama, Kelebihan. Buku teks pelajaran yang baik, dikatakan baik dan berkualitas jika memenuhi kriteria buku yang baik pula. Dalam buku teks yang dikaji dalam makalah ini, bahwa segala aspek yang termuat dalam kriteria buku yang baik sudah terpenuhi meskipun belum dapat dikatakan secara sempurna. Ditinjau dari aspek relevansi kurikulum, buku teks bahasa Arab untuk kelas VI sudah sesuai dengan standar isi yang tercantum dalam KTSP yang berlaku yaitu dengan mempertimbangkan empat aspek keterampilan berbahasa.

Tema-tema yang dipilih juga sesuai dengan perkembangan siswa dan lingkungan siswa khususnya kelas VI Madrasah Ibtidaiyah. Ditinjau dari aspek kebahasan, juga menggunakan bahasa-bahasa (istilah kosa kata) yang mudah, disamping adanya kosa kata baru sebagai pengayaan. Ilustrasi, gambar dan grafik yang ditampilkan juga cukup mewakili dunia siswa dari aspek perkembangan usia, khususnya untuk kelas VI (enam) Madrasah Ibtidaiyah. Ilustrasi atau gambar yang disajikan sesuai dengan tema pokok bahasan.Ditinjau dari jumlah halaman, bahwa buku teks pelajaran ini berisi cukup karena hanya 96 (sembilan puluh enam) halaman.

Kedua, Kekurangan. Selain kelebihan yang dimiliki oleh buku teks pelajaran bahasa Arab tersebut, maka buku ini juga mempunyai kekurangan. Adapun kekurangan yang tampak dalam buku teks ini tidak terlalu signifikan. Ilustrasi yang digambarkan dalam buku masih belum merangsang minat siswa. Karena ditinjau dari segi pewarnaan yang dipilih hanya terbatas pada warna hitam, putih dan abu-abu. Penyajian tata bahasa masih belum luas, terbatas pada dhomir, ism isyaroh dan ism mudzakar dan muannats. Pada aspek terjemah 
dari bahasa Indonesia ke bahasa Arab terkadang masih menggunakan istilah yang cukup sulit bagi siswa kelas VI.

\section{Kesimpulan}

Dari hasil analisi buku Bahasa Arab karya Dr. D. Hidayat untuk siswa kelas VI MI ini, dapat disimpulkan sebagai berikut: Pertama, buku ini sudah memenuhi kriteri penyusunan buku yang baik meskipun belum bisa dikatakan sempurna. Sedangkan relevansinya dengan kurikulum memenuhi syarat yang telah ditentukan.

Dari beberapa temuan yang menjadi kekurangan dalam buku ini dapat maka seyogyanya buku ini dikembangkan dan didesain kembali lebih rapi dan menarik sehingga para siswa dapat termotivasi untuk belajar dengan menggunakan buku ini. 


\section{DAFTAR PUSTAKA}

---------.2007b.KTSP: Pembelajaran Berbasis Kompetensi dan Kontekstual.

Ahmad Sudrajat, "Konsep Sumber Belajar dalam

http://akhmadsudrajat. wordpress.com/2008/04/15/, diakses Agustus 2020

Anselm strauss dan Juliet Corbin, (2003). Dasar-Dasar Penelitian Kualitatif, Yogyakarta: Pustaka Pelajar.

Departemen Agama RI. (2004). Kurikulum 2004: Standar Kompetensi Madrasah Ibtidaiyah. Jakarta: Direktorat Jenderal Kelembagaan Agama Islam.

Departemen Agama RI.(2004) Kurikulum 2004: Standar Kompetensi

Departemen Agama RI.(2005). Kurikulum 2005: Standar Kompetensi Madrasah Tsanawiyah. Jakarta: Direktorat Jenderal Kelembagaan Agama Islam.

Dr. D. Hidayat, (2008) Pelajaran Bahasa Arab/تعليم اللغة العربية", Semarang: Karya Toha Putra

Drost, J. Sj..(2005). Dari KBK (Kurikulum Bertujuan Kompetensi) Sampai MBS (Manajemen Berbasis Sekolah). Jakarta: Penerbit Buku Kompas.

Hadari Nawawi dan Mimi Martini, (2005). Penelitian Terapan, Yogyakarta: Gadjah Mada University Press, Jakarta: PT Bumi Aksara.

John. W. Best, (1982). Metode Penelitian Pendidikan, Surabaya: Usaha Nasional

Krashen, S.D. and Tracy D. Terrell .1983.The Natural Approach: Language Acquisition in the Classroom. New York: Pergamon Press.

Madrasah Tsanawiyah. Jakarta: Direktorat Jenderal Kelembagaan Agama Islam. Moh.Nazir, (1999). Metode Penelitian, Jakarta: Ghalia Indonesia, Muslich, Mansur.(2007) KTSP (Kurikulum Tingkat Satuan Pendidikan) Pendidikan: Konsep dan Implementasinya di Madrasah. Yogyakarta: Pilar Media, 